\title{
Implementation of PjBL-STEM to Improve Students' Creative Thinking Skills On Static Fluid Topic
}

\author{
Asep Saefullah ${ }^{1}$, Andri Suherman ${ }^{2}$, Riska Tri Utami ${ }^{3}$, Ganesha Antarnusa ${ }^{4}$, Diana Ayu \\ Rostikawati ${ }^{5}$, Robby Zidny ${ }^{6}$ \\ Universitas Sultan Ageng Tirtayasa, Indonesia ${ }^{1,2,3,4,6}$, Universitas Bina Bangsa, Indonesia ${ }^{5}$, \\ University of Bremen, Germany ${ }^{6}$ \\ asaefullah@untirta.ac.id ${ }^{1}$, andris_mada@yahoo.com², riskatriutami09@gmail.com³, \\ ganesha.antarnusa@untirta.ac.id ${ }^{4}$, dianaayu0889@gmail.com ${ }^{5}$, zidny@ uni-bremen.de ${ }^{6}$
}

Received: June $18^{\text {th }}, 2020$. Revised: December $15^{\text {th }}, 2020$. Accepted: January $7^{\text {th }}, 2021$

Keywords :

Project-Based Learning

(PjBL)-STEM; Creative

Thinking Skills; Static Fluid

Materials (Pascal Law)

\begin{abstract}
This research aims to investigate the influence of ProjectBased Learning (PjBL)-Science, Technology, Engineering, and Mathematics (STEM) on Students' Creative Thinking Skills. The research method was quasi-experiment using a nonequivalent control group design. Samples were taken using purposive sampling technique from two of $11^{\text {th }}$-grade science classes as an experimental and a control groups. This study used a test instrument of creative thinking skills. Research data were analyzed using SPSS and Microsoft Excel software. Hypothetical test results were assessed using independent sample t-test, obtained sig value (2tailed $)=0.01$ indicating sig value $<0.05$. According to statistical analysis, there is a significant difference between the control class and the experiment class. The n-gain value was obtained with a score of 0.59 (a medium category). This result shows that the application of PJBL-STEM can improve students' creative thinking skills in the static fluid topic (Pascal law).
\end{abstract}

\section{INTRODUCTION}

Education today should be able to produce human resources (HR) that have 21st-century skills [1] [2]. The 21st-century skills consist of four components, namely: (1) Critical Thinking and Problem-Solving ability, (2) Communication ability, (3) Collaboration (cooperation with others), and (4) Creativity and Innovation [3]. One component of 21st-century skills that students should have is creative thinking. Creative thinking is an individual ability to create or produce something new, whether it is an idea or a product which still related to a product that ever existed [4]. Creative thinking is a form of selfexpression that is showed uniquely [5]. There are four indicators of creative thinking skills: (1) Fluency, (2) Flexibility, (3) Originality, and (4) Elaboration [6].

Based on field studies, physics learning in the classroom is still dominated by a teacher-centred approach, where teachers become the only learning resource. Accordingly, students are less active in the learning process, and it is resulting in low creative thinking skills. Creative thinking skills can be 
Implementation of PjBL-STEM to Improve Students' Creative Thinking Skills On Static Fluid Topic Asep Saefullah, Andri Suherman, Riska Tri Utami, Ganesha Antarnusa, Diana Ayu Rostikawati, Robby Zidny

improved through various training efforts [7]. One of the efforts in improving creative thinking skills is to implement innovative learning models or approaches. Some learning models can facilitate learners to be active in the learning process, such as Inquiry-Based Learning models integrated mind map [8], Problem Based Learning (PBL) assisted multimedia [9], Guided Discovery models [10], project-based learning models [11] [12], or constructivism approaches [13].

Project-based learning (PjBL) is one of the learning approaches for students to construct knowledge in groups with scientific methods [14]. In PjBL, students can define their own learning process in groups, conduct research and create creative project projects that can explore their knowledge [15]. Currently, Science learning must combine science and technology and other disciplines. This can be done through the integration of Science, Technology, Engineering, and Mathematics (STEM) in learning. STEM approaches to learning are expected to produce meaningful learning for students through the mathematical integration of knowledge, concepts, and skills [16]. The PjBL-STEM relationship can be used as an innovative learning approach, and wherein $\mathrm{PjBL}$ students are required to create a project or create a tool, while STEM is a component that has a connection between across disciplines. STEM integration in the PjBL model results in five learning syntax, namely: (1) Reflection, (2) Research, (3) Discovery, (4) Application, and (5) Communication [17].

Based on previous research, PjBL-STEM has some significant impact in science learning, for example: to improve science literacy [18], improve problem-solving skills [19] [20], improve mastery of student concepts and learning activities [21], or to improve metacognitive skills [22].

The application of STEM integrated PJBL models is suitable for teaching the static fluid topic that addresses Pascal's law [23]. The Core Competency (KI) and Basic Competency (KD) on static fluid themes are applying the static fluid laws in daily life (in KI 3.3), and designing and conducting experiments utilizing static fluid properties, as well as presenting the results of experiments and their utilization (in KI 3.4). Based on KI 3.3 and KD 3.4, it appears that students are required to design and conduct experiments, which can be facilitated through an integrated STEM PJBL model. Pascal's law is the fundamental law of the concept of static fluid, which addresses fluid pressure in enclosed spaces [24]. There are many Pascal's law applications, for example on hydraulic jacks, hydraulic brakes, excavators, and so on.

Based on the above description, the research was selected with the theme "Implementation of PJBLSTEM To Improve Students' Creative Thinking Skills in Static Fluid Topic (Pascal's Law)". The formulation of the research questions are (1) whether the application of PJBL- STEM can improve students' creative thinking skills in static fluid materials (Pascal's law), (2) How to analyze students' creative thinking skills using PjBL-STEM and Direct instruction models on static fluid material (Pascal's law), (3) How is the student's creative thinking ability for each indicator.

\section{METHOD}

The study used a pretest-posttest nonequivalent control group design. In this design, there were two groups that each group is not randomly selected, but has been specified in advance. The population in this study is $11^{\text {th }}$ grade upper secondary school student from Madrasah Aliyah Negeri in Lebak district, and the sample used is 2 sample classes with each class of 30 people. Samples were taken using purposive sampling technique, which is divided into two classes. The first group was an experimental class group treated with the PjBL-STEM model, and the second group was a control class group not treated. The design of the research can be seen in table 1 [25].

Table 1. Pretest-Posttest Research Design nonequivalent control group design

\begin{tabular}{cccc}
\hline Group & Pretest & Treatment & Posttest \\
\hline Experiment Class & $\mathrm{O}_{1}$ & $\mathrm{X}$ & $\mathrm{O}_{2}$ \\
Control Class & $\mathrm{O}_{3}$ & & $\mathrm{O}_{4}$ \\
\hline
\end{tabular}


Description :

$\mathrm{X}=\mathrm{PjBL}-\mathrm{STEM}$

In the PjBL-STEM model, there is a learning syntax as in table 2.

Table 2. PjBL-STEM Syntax

$\begin{array}{cl}\begin{array}{c}\text { PjBL-STEM } \\ \text { Syntax }\end{array} & \text { Activities in the classroom } \\ \text { Reflection } & \text { The teacher gives questions regarding the concept of Pascal's legal application to } \\ & \text { explore the student's early understanding. } \\ \text { Example question: How does hydraulic brake work in the car's braking process? } \\ \text { How to lift a vehicle with the hydraulic pump when tires leak? }\end{array}$

A research instrument is required to investigate the impact of PjBL-STEM in improving creative thinking skills. The research instrument used in this study was five items essay questionnaires which consist of four indicators of creative thinking skills. Furthermore, the research instruments were validated by expert judgement and using the calculation of content validity ratio (CVR) and content validity index (CVI). The results of the validity test showed the instruments were valid, with a score of 0.42 (medium) [13]. The indicators of creative thinking skills were shown in table 3 [14]. 
Implementation of PjBL-STEM to Improve Students' Creative Thinking Skills On Static Fluid Topic Asep Saefullah, Andri Suherman, Riska Tri Utami, Ganesha Antarnusa, Diana Ayu Rostikawati, Robby Zidny

Table 3. Creative Thinking Skills Indicators

\begin{tabular}{|c|c|c|c|}
\hline No & Indicators & Sub-indicator & $\begin{array}{l}\text { Question } \\
\text { number }\end{array}$ \\
\hline 1 & Fluency & $\begin{array}{l}\text { Have many answers and ideas in solving a problem. } \\
\text { - } \quad \text { Students are expected to have various alternative answers } \\
\text { related to the problem of building in areas with mushy soil } \\
\text { structures by applying the concept of pressure. }\end{array}$ & 1 \\
\hline 2 & Flexibility & $\begin{array}{l}\text { Have different ideas and answers to others in solving a } \\
\text { problem. } \\
\text { - Students are expected to have various answers related to the } \\
\text { different problems of hydrostatic pressure experienced by } \\
\text { people swimming in freshwater pools by swimming in the } \\
\text { sea. So divers at sea must be equipped with special } \\
\text { equipment. }\end{array}$ & 4 \\
\hline 3 & Originality & $\begin{array}{l}\text { Produce a different way of thinking according to his own } \\
\text { thinking } \\
\text { - Students are expected to have an original idea in the form } \\
\text { of utilizing objects around the environment to create } \\
\text { science projects from pascal law application, where the } \\
\text { project can also be used for gaming facilities. } \\
\text { - In addition, students are also expected to have a various } \\
\text { original idea about the structure of a dam, in order to } \\
\text { withstand the large hydrostatic pressure of water. }\end{array}$ & 2,5 \\
\hline 4 & Elaboration & $\begin{array}{l}\text { Generate a broader idea of a problem so that it can solve the } \\
\text { problem in detail. } \\
\text { - Students are expected to have detailed answers to solve a } \\
\text { given problem, related to how the brakes work to stop a } \\
\text { large-time car in an easy style, associated with Pascal's law } \\
\text { application. } \\
\text { - Or how to lift a car with a large mass when the car has a } \\
\text { tire bomb or will be washed, in a small style. Associated } \\
\text { with the broad form of lever pipe and lifting pipe. }\end{array}$ & 3 \\
\hline
\end{tabular}

Data analysis was conducted quantitatively to find out the improvement of creative thinking skills. The data were analyzed statistically to ensure normality and homogeneity. The normality of the data was tested using the Wilk Shapiro test, and the homogeneity was assessed using the Levene test with the score of $\alpha=0.05$. Furthermore, the data was assessed with a parametric test. An independent t-test was used to ensure there is no difference in scores in the experiment class and control of students' creative thinking skills. A further analysis using $\mathrm{N}$-Gain was conducted to test whether there is an increase in students' creative thinking [26]. The N-Gain formula used is

$$
\langle g\rangle=\frac{X_{\text {post }}-X_{\text {pre }}}{X_{\text {max }}-X_{p r e}}
$$

Description :

$\langle g\rangle=$ Gain value

$X_{\text {post }}=$ Posttest score

$X_{\text {pre }}=$ Pretest score

$X_{\text {max }}=$ Maximum score

The criteria for $\mathrm{n}$-gain value can be seen in the following table 3 . 
Table 3. N-gain value criteria

\begin{tabular}{cc}
\hline N-gain value & Criteria \\
\hline$\langle g\rangle>0,7$ & High \\
$0,3 \leq\langle g\rangle \leq 0,7$ & Medium \\
$\langle g\rangle<0,3$ & Low \\
\hline
\end{tabular}

\section{RESULTS AND DISCUSSIONS}

The teaching intervention in this PJBL-STEM was to engage the student's project to create tools related to pascal law, as shown in table 2. The tool was made to resemble a game to make students more motivated and think creatively. The tools name was Pascal Maze, which applies pascal law in the form of a labyrinthine game, as shown in figure 1 .
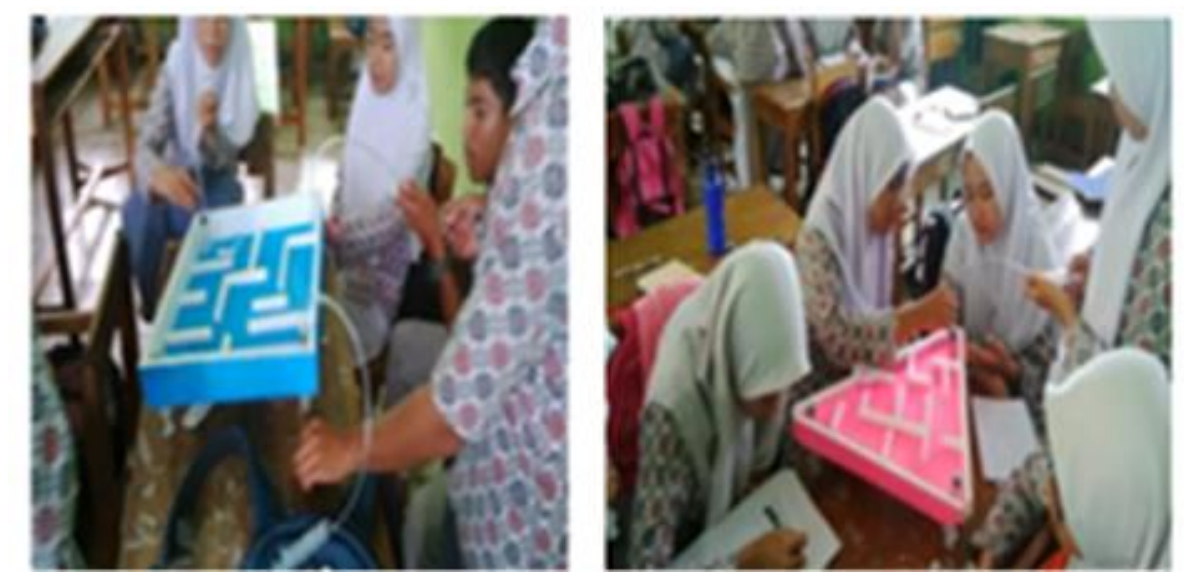

Fig 1. Student Products, Square Pascal Maze (left) and Traingular pascal Maze (right)

The $\mathrm{N}$ gain value was assessed using Ms. Excel software to find out the improvement of the creative thinking skills of students. Table 4 shows the recapitulation of pretest-posttest values in control classes and experiments.

Table 4. Pretest-Posttest values control class and experiment class

\begin{tabular}{cccc}
\hline Description & Minimum & Maximum & Mean \\
\hline Pre_Experiment & 16 & 76 & 39.20 \\
Post_Experiment & 36 & 100 & 75.60 \\
Pre_control & 16 & 68 & 38.27 \\
Post_control & 20 & 92 & 59.73 \\
\hline
\end{tabular}

Based on the analysis of the data, the result indicates that the creative thinking skills for the pretest scores on the experiment are higher than the control class, with a mean score of 39.20. The average score in the pretest on both control or experiment classes are relatively small because both classes have not obtained any intervention from PJBL-STEM or conventional learning. Unlike pretest scores, posttest scores obtain a reasonably high average in both control and experiment classes. However, in the experiment class, the average posttest score was more than the control class, with the score 75.60. The improvement of the students' creative thinking skills can be seen in table 5 . 
Implementation of PjBL-STEM to Improve Students' Creative Thinking Skills On Static Fluid Topic Asep Saefullah, Andri Suherman, Riska Tri Utami, Ganesha Antarnusa, Diana Ayu Rostikawati, Robby Zidny

Table 5. N-Gain value creative thinking skills in Experiment Class and Control class

\begin{tabular}{ccc}
\hline Description & Experiment Class & Control Class \\
\hline N-Gain & 0.59 & 0.33 \\
N-Gain criteria & Medium & Medium \\
Number of students & 30 & 30 \\
\hline
\end{tabular}

The result of $\mathrm{N}$ Gain creative thinking skills in the control class was 0.33 , while in the experiment class was 0.59 . Based on these values, it can be interpreted that both classes have a moderate $n$ gain value. However, in the experiment class, the $\mathrm{N}$ gain score is greater than the control class. This is in accordance with previous research that stated that the use of PjBL-STEM models is able to improve students' creative thinking skills [27] [28].

Research hypothesis testing was conducted to find out the differences in creative thinking skills in experiment classes and control classes. Hypothesis testing using an independent t-test. The test hypothesis used is Ho: There is no significant difference in the value of creative thinking skills test before and after learning; Ha : There is a significant difference in the value of creative thinking skills test before and after learning. The test hypothesis is: $\mathrm{Ho} \geq 0.05$; then Ho was accepted and Ha was rejected; Ho < 0.05; then Ho was rejected and Ha accepted. The independent t-test results are found in table 6.

Table 6. Independent t-test

\begin{tabular}{|c|c|c|c|c|c|c|c|c|}
\hline & & \multirow{3}{*}{$\mathbf{T}$} & \multirow{3}{*}{ Df } & \multirow{3}{*}{$\begin{array}{l}\text { Sig. (2- } \\
\text { tailed) }\end{array}$} & \multicolumn{4}{|c|}{ t-test for Equality of Means } \\
\hline & & & & & \multirow[t]{2}{*}{$\begin{array}{c}\text { Mean } \\
\text { Difference }\end{array}$} & \multirow[t]{2}{*}{$\begin{array}{l}\text { Std. Error } \\
\text { Difference }\end{array}$} & \multicolumn{2}{|c|}{$\begin{array}{l}95 \% \text { Confidence } \\
\text { Interval of the } \\
\text { Difference }\end{array}$} \\
\hline & & & & & & & Lower & Upper \\
\hline $\begin{array}{l}\text { Post-test } \\
\text { experiment } \\
\text { and control }\end{array}$ & $\begin{array}{l}\text { Equal variances } \\
\text { assumed }\end{array}$ & 3.446 & 58 & .001 & 15.867 & 4.604 & 6.651 & 25.083 \\
\hline
\end{tabular}

Based on table 6 , the sig value is known. (2-tailed) $<0.05$, which means Ho is rejected and $\mathrm{Ha}$ is accepted. This means that there is a significant (noticeable) difference between the experiment class and the control class. In class control, the PjBL-STEM model affects students' creative thinking skills [29]. STEM project-based learning helps students connect the knowledge gained with its application in real life. Integration between science, technology, engineering and mathematics (STEM) help students understand that there are linkages across fields of science [30].

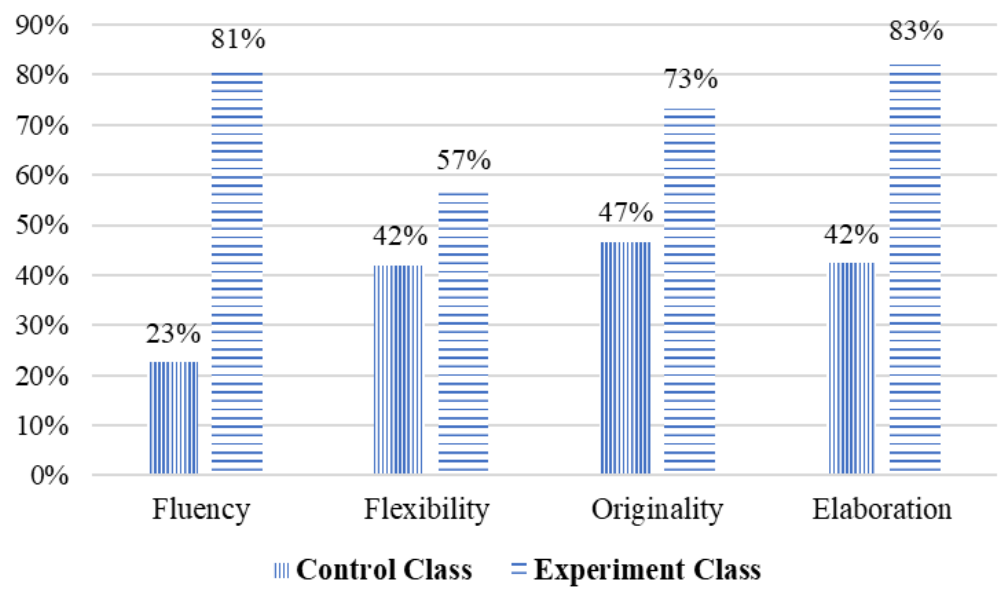

Fig 2. Student Creative Thinking Skills Analysis 
The students' creative thinking skills data on each indicator (fluency, flexibility, originality and elaboration) is processed using Ms. Excel software. The results of the analysis of creative thinking skills are listed in figure 2. Figure 2 shows the analysis of the creative thinking skills of each indicator in the experiment class higher than the control class. This result was obtained because the integrated PjBLSTEM model integrated into experimental classes, while the control classes only receive conventional learning. In the experiment class, the average value of creative thinking skills was $73.75 \%$, while the control class only gained a creative thinking skill score of $38.42 \%$. In the experiment class, the elaboration indicator has the highest percentage score compared to others, indicating that students have the ability to solve the problem in detail. While the fluency indicator has the lowest score compared the other, indicating that students do not have various answers related to the different problems.

The implementation of PJBL-STEM in experiment class increase all aspects of student's creative thinking skills. This result is indicated by the n-gain value shown in Figure 3. Fluency and Elaboration indicators obtain n-gain values with high criteria, Originality indicator obtained n-gain value with medium criteria, while the Flexibility indicator obtained the n-gain value with low criteria. This indicated that the PJBL-STEM had facilitated students to improve their creative thinking skills.

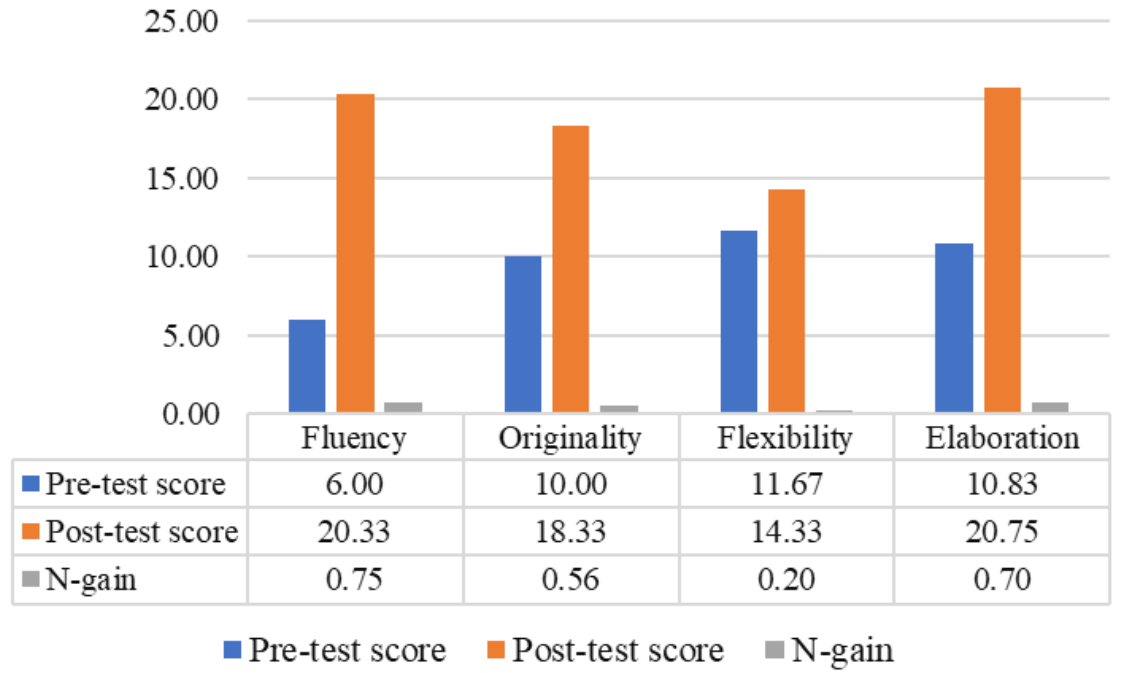

Fig 3. Average Scores of Pretest, Posttest, and N-gain for Each Indicator of Creative Thinking Skills

The highest increase in critical thinking skills was found in the fluency indicator. This result is the same as previous research, which shows that the fluency indicator has the highest increase after being given STEM-based learning [31]. The increase in creative thinking skills on the fluency indicator shows that students are fluent in explaining solutions to a problem. Students are expected to have various alternative answers related to the problem of building in areas with mushy soil structures by applying the concept of pressure.

\section{CONCLUSION AND SUGGESTION}

Based on the results of the research, it can be concluded that PjBL-STEM model can improve students' creative thinking skills in the static fluid topic (Pascal's law). Although control class can equally enhance creative thinking skills, the average score in the experiment class is greater than the control class. Based on the results of statistical analysis, it can be seen that there is a significant difference between the experiment class and the control with a sig value of 2 tailed $<$ of 0.05 .

The result of the study provides some implications for future physics learning and research. The teachers/schools are suggested to improve high-level thinking skills in students, especially creative 
Implementation of PjBL-STEM to Improve Students' Creative Thinking Skills On Static Fluid Topic Asep Saefullah, Andri Suherman, Riska Tri Utami, Ganesha Antarnusa, Diana Ayu Rostikawati, Robby Zidny

thinking skills. A learning model of PjBL-STEM is needed to enhance the imagination, creativity and activity of students. For future research, applying the PjBL-STEM model should be developed with other, more challenging physics learning topic.

\section{REFERENCES}

[1] Liana, Y. R., \& Nursuhud, P. I. (2020). Problem-Based Learning Approach with Supported Interactive Multimedia in Physics Learning: Its Effects on Critical Thinking Abilty. JIPF (Jurnal Ilmu Pendidikan Fisika), 5(2): 88-97.

[2] Wijaya, E. Y., Sudjimat, D. A., Nyoto, A., \& Malang, U. N. (2016). Transformasi pendidikan abad 21 sebagai tuntutan pengembangan sumber daya manusia di era global. In Prosiding Seminar Nasional Pendidikan Matematika (Vol. 1, No. 26, pp. 263-278).

[3] Mahanal, S. (2014, September). Peran Guru dalam Melahirkan Generasi Emas dengan Keterampilan Abad 21. In Seminar Nasional Pendidikan HMPS Pendidikan Biologi FKIP Universitas Halu Oleo (pp. 1-16).

[4] Im, H., Hokanson, B., \& Johnson, K. K. (2015). Teaching creative thinking skills: A longitudinal study. Clothing and Textiles Research Journal, 33(2): 129-142.

[5] Fitria, C. (2015). Profil keterampilan berpikir kreatif siswa dalam memecahkan masalah matematika ditinjau dari tipe kepribadian (sanguinis, koleris, melankolis, dan phlegmatis). MATHEdunesa, 3(3).

[6] Treffinger, D. J., Young, G. C., Selby, E. C., \& Shepardson, C. (2002). Assessing Creativity: A Guide for Educators. National Research Center on the Gifted and Talented.

[7] Ritter, S. M., \& Mostert, N. (2017). Enhancement of creative thinking skills using a cognitivebased creativity training. Journal of Cognitive Enhancement, 1(3): 243-253.

[8] Zubaidah, S., Fuad, N. M., Mahanal, S., \& Suarsini, E. (2017). Improving creative thinking skills of students through differentiated science inquiry integrated with mind map. Journal of Turkish Science Education, 14(4): 77-91.

[9] Nulhakim, L., Setiawan, F. R., \& Saefullah, A. (2020). Improving Students' Creative Thinking Skills Using Problem-Based Learning (PBL) Models Assisted by Interactive Multimedia. Jurnal Penelitian \& Pengembangan Pendidikan Fisika, 6(1): 9-16.

[10] Rohim, F., \& Susanto, H. (2012). Penerapan model discovery terbimbing pada pembelajaran fisika untuk meningkatkan kemampuan berpikir kreatif. UPEJ Unnes Physics Education Journal, 1(1).

[11] Marlinda, N. L. P. M. (2012). Pengaruh model pembelajaran berbasis proyek terhadap kemampuan berpikir kreatif dan kinerja ilmiah siswa. Jurnal Pendidikan dan Pembelajaran IPA Indonesia, 2(2).

[12] Luthvitasari, N., \& Linuwih, S. (2012). Implementasi pembelajaran Fisika Berbasis Proyek terhadap keterampilan berpikir kritis, berpikir kreatif dan kemahiran generik sains. Journal of innovative Science education, 1(2).

[13] Fitriarosah, N. (2016). Pengembangan Instrumen Berpikir Kreatif Matematis Untuk Siswa SMP. In Prosiding Seminar Nasional Pendidikan Matematika (Vol. 1, pp. 243-250).

[14] Azhari, A., \& Somakim, S. (2014). Peningkatan Kemampuan Berpikir Kreatif Matematik Siswa Melalui Pendekatan Konstruktivisme Di Kelas Vii Sekolah Menengah Pertama (Smp) Negeri 2 Banyuasin III. Jurnal Pendidikan Matematika, 8(1): 1-12.

[15] Tseng, K. H., Chang, C. C., Lou, S. J., \& Chen, W. P. (2013). Attitudes towards science, technology, engineering and mathematics (STEM) in a project-based learning (PjBL) environment. International Journal of Technology and Design Education, 23(1): 87-102.

[16] Chen, C. S., \& Lin, J. W. (2019). A practical action research study of the impact of maker-centered STEM-PjBL on a rural middle school in Taiwan. International Journal of Science and Mathematics Education, 17(1): 85-108.

[17] Afriana, J., Permanasari, A., \& Fitriani, A. (2016). Penerapan project based learning terintegrasi STEM untuk meningkatkan literasi sains siswa ditinjau dari gender. Jurnal Inovasi Pendidikan IPA, 2(2): 202-212.

[18] Laboy-Rush, D. (2011). Integrated STEM education through project-based learning. Portland, United States of America: Sematinticscholar.org. 
[19] Mustikasari, V. R., Yulianti, E., Pratiwi, N., Hidayat, A., Pryadiani, A. K., \& Phang, F. A. (2020, April). The implementation of PjBL-STEM model to improve eight graders' scientific literacy. In AIP Conference Proceedings (Vol. 2215, No. 1, p. 040009). AIP Publishing LLC.

[20] Purwaningsih, E., Sari, A. M., Yuliati, L., Masjkur, K., Kurniawan, B. R., \& Zahiri, M. A. (2020, March). Improving the problem-solving skills through the development of teaching materials with STEM-PjBL (science, technology, engineering, and mathematics-project based learning) model integrated with TPACK (technological pedagogical content knowledge). In Journal of Physics: Conference Series (Vol. 1481, No. 1, p. 012133). IOP Publishing.

[21] Yuliati, L., Munfaridah, N., Ali, M., Rosyidah, F. U. N., \& Indrasari, N. (2020, April). The effect of project based learning-STEM on problem solving skills for students in the topic of electromagnetic induction. In Journal of Physics Conference Series (Vol. 1521, No. 2, p. 022025).

[22] Astuti, I. D., Toto, T., \& Yulisma, L. (2019). Model Project Based Learning (Pjbl) Terintegrasi Stem Untuk Meningkatkan Penguasaan Konsep Dan Aktivitas Belajar Siswa. Quagga: Jurnal Pendidikan dan Biologi, 11(2): 93-98.

[23] Wangguway, Y., Kurniawati, S., Maylisa, I. N., Al Jabbar, Z. L., \& Sulistiyono, B. (2020, June). The analysis of STEM-PjBL implementation and its effect on students' metacognition skills in resolving social arithmetic problems. In Journal of Physics: Conference Series (Vol. 1563, No. 1, p. 012048). IOP Publishing.

[24] Yuliati, L., Ndadari, I. P., \& Ali, M. (2020, March). Project Based Learning Integrated STEM to Increase Students' Scientific Literacy of Fluid Statics Topic. In Journal of Physics: Conference Series (Vol. 1491, No. 1, p. 012030). IOP Publishing.

[25] Halliday, D., Resnick, R., \& Walker, J. (2013). Fundamentals of physics. John Wiley \& Sons.

[26] Sugiyono, P. (2011). Metodologi penelitian kuantitatif kualitatif dan R\&D. Bandung: Alpabeta.

[27] Meltzer, D. E. (2002). The relationship between mathematics preparation and conceptual learning gains in physics: A possible "hidden variable" in diagnostic pretest scores. American journal of physics, 70(12): 1259-1268.

[28] Kristiani, K. D., Mayasari, T., \& Kurniadi, E. (2017, August). Pengaruh pembelajaran STEM-PjBL terhadap keterampilan berpikir kreatif. In Prosiding SNPF (Seminar Nasional Pendidikan Fisika) (pp. 266-274).

[29] Lestari, T. P., Sarwi, S., \& Sumarti, S. S. (2018). STEM-based Project Based Learning model to increase science process and creative thinking skills of 5 th grade. Journal of primary education, 7(1): 18-24.

[30] Hanif, S., Wijaya, A. F. C., \& Winarno, N. (2019). Enhancing Students' Creativity through STEM Project-Based Learning. Journal of Science Learning, 2(2): 50-57.

[31] Sumarni, W., \& Kadarwati, S. (2020). Ethno-Stem Project-Based Learning: Its Impact to Critical and Creative Thinking Skills. Jurnal Pendidikan IPA Indonesia, 9(1): 11-21. 